\title{
A REAL OPTIONS MODEL FOR ANALYSIS OF INDUSTRIAL R\&D EXPENDITURES
}

\author{
A.V.BUKHVALOV, A.E. LOUKIANOVA, E. D. NIKULIN, V.L. OKULOV \\ Saint Petersburg University, Russia
}

\begin{abstract}
The objective of this paper is to develop the model that can be used to explain the amount of research and development (R\&D) expenditures of large and mature companies. The research methodology is based on real options approach. We model companies' R\&D expenditures as payments for the real option, which is the right of a company to invest in real assets in the future, and therefore to ensure business development. The main result is a valuation model, which includes several relevant factors. While existing research papers apply real options approach mostly to the R\&D projects of particular companies or within particular industries and situations, the current paper applies the corresponding methodology in general and aggregated setting. We hope that it will contribute to understanding of $R \& D$ intensity in large innovative companies.
\end{abstract}

Keywords: R\&D expenditures, R\&D projects portfolio, real option approach, volatility of company value.

JEL: C65, G13, G32, M11, O32.

Nowadays many companies typically spend large amounts of money on R\&D. For large companies $\mathrm{R} \& \mathrm{D}$ expenditures constitute a large share of their annual revenue. For example, in 2016 Intel spent on R\&D activities approximately $22 \%$ of its revenue, while for Bristol-Myers Squibb the corre- sponding ratio is $36 \%$. Another distinctive feature of corporate R\&D spending is that industrial leaders are engaged in $R \& D$ activities on a constant basis. Indeed, nine companies (Volkswagen, Toyota, Samsung, Intel, Microsoft, Roche, Novartis, Pfizer, $J \& J)$ are in the list of top 20 world R\&D

Research was conducted with financial support from the grant provided by St. Petersburg University (project No. 16.23.1460.2017).

Postal Address: St. Petersburg University, Russia, 7/9 University emb., St.Petersburg, 199034, Russian Federation.

(C) A.V.Bukhvalov, A.E.Loukianova, E.D. Nikulin, V.L.Okulov, 2018

https://doi.org/10.21638/spbu18.2018.304 
spenders for ten years straight [Jaruzelski, Schwartz, Staack, 2015].

The analysis of statistical data presented in [Jaruzelski, Schwartz, Staack, 2015] reveals that the amount of $R \& D$ spending is significantly industry-dependent. Companies with the most significant R\&D expenditures belong to the computing and electronics, healthcare, and auto sectors. Moreover, even within a single industry the amount of R\&D investments can vary from company to company. For example, in 2015 Intel and Apple, both included into the computing and electronics industry, demonstrated different numbers in terms of R\&D spending: Intel spent $20.6 \%$ in 2015 on $R \& D$, while Apple spent $3.3 \%$.

Overall, these large costs should look unfavorable to companies' shareholders because R\&D spending itself does not create value. In other words, R\&D spending should in theory have negative net present value because, being fixed nonmanufacturing costs, these expenditures lower profits and as a result should eventually undermine companies' market capitalization. Nevertheless, the analysis of business practice reveal that $R \& D$ spending increases companies' financial results in the long run and therefore these costs are perceived favorably by shareholders. For example, the Golden Sachs report reveals strong positive relation between $R \& D$ spending, sales growth and stock returns for eight years to 2012 for the companies of technology, Internet, and biotech sectors. The academic research brought similar results. For example, [Ding, Stolowy, Tenenhaus, 2007] using the cross-country sample of companies from Canada, Germany, Japan, Switzerland, the UK, and the USA show that $R \& D$ expenditures contribute to future earnings, although the amount of this contribution varies between countries. On the sample of OECD countries [Aydin, Alrajhi, Jouini, 2018] reveal that R\&D expenditures is one of the drivers of total economic productivity.
Apparently, potential positive impact of $R \& D$ spending on future earnings is due to the fact that the results of $R \& D$ activities in the case of their successful implementation can provide companies with capabilities to produce goods using some advanced technology or to produce fundamentally new products. In order to exploit these benefits, however, companies need to invest in manufacturing of these products or in change of technologies. R\&D activities provide the justification for such investments or, in other words, without R\&D these investments can hardly be possible. One of the main research questions is to assess the feasible amount of $R \& D$ expenditures.

The real options approach is one of the commonly used methods to assess R\&D spending of companies. Here a company faces many kinds of uncertainty. The key idea is that $\mathrm{R} \& \mathrm{D}$ spending can be considered as a payment for acquiring the exclusive right to make investments in real assets in the future. Such an approach explicitly allows the treatment of $\mathrm{R} \& \mathrm{D}$ spending as a real option.

Despite the fact that the real option approach is frequently applied to assessing $\mathrm{R} \& \mathrm{D}$ projects, as far as we know, there is a lack of studies that directly apply this approach to explain industrial differences of companies in R\&D spending. Thus, the goal of our paper is to propose a model to assess the industrial R\&D intensity by treating $R \& D$ expenditures as the value of a real option.

The structure of the paper is as follows. Section 1 introduces general framework on real R\&D options. Section 2 presents the problem and assumptions used in our original research model. Section 3 provides the detailed description of the model at the company level whereas Section 4 does the same at industry level in the terms of R\&D intensity indicator. Main formulas (6) and (12) for R\&D expenditure are derived. Section 5 is devoted to some empiri-

RMJ 16 (3): 393-406 (2018) 
cal validation of these formulas. Section 6 concludes and outlines some directions for further research.

\section{Real R\&D options}

In financial literature extensive elaboration of real options theory has started in 1980s with introduction of powerful research tools for their use in various areas of finance and strategic management. The main contributions include understanding of valuation and decision making in uncertain world, which takes into account irreversibility of investments and flexibility of managerial decisions. The concept of riskneutral valuation or, better to say, that of decision making in risk-neutral environment, has been in the center of techniques starting from the seminal Black-Scholes contribution (see [Hull, 2012] for the history). This technique is the main tool in construction of our model.

During 1990s a bulk of literature with applications of real options to various areas of management has appeared. Among those were strategic management, IT investment and $R \& D$ investment. After the special issue in $R \& D$ Management journal (see [Paxson, 2001] and other papers of the issue) and [Newton, Paxson, Widdicks, 2004] the notion of real R\&D option has been widely accepted. Actually the variety of understandings of R\&D investments and associated options thereof is almost inexhaustible. [Teece, 2018] emphasizes many different types of R\&D projects. In [Childs, Triantis, 1999] authors show many different R\&D investment strategies that provide important flexibility for the projects (usually multi-stage analysis is involved). In [Oriani, Sobrero, 2008] they analyze different types of uncertainty (market vs technology). Paper [Cuervo-Cazurra, Un, 2010] relates R\&D investments of a company with its knowledge resources. Authors [Chakravarty, Grewal, 2011] analyze the behavior of managers in response to stock mar- ket reaction on R\&D investments. This issue is related both to growth options and marketing budget.

We also should mention that the majority of papers are devoted to the use of real options methodology for companies from specific industries. For instance, [Choi, Kwak, Yoo, 2016] apply real options approach to the deep seabed manganese nodule mining projects. Their results reveal that the project, indeed, has economic potential that was not captured by traditional valuation methods such as discounted cash flow (DCF) approach. In [Managi, Zhang, Horie, 2016] scholars use real option approach to account for different types of uncertainty in the environmental project. [Kellogg, Charnes, 2000] discuss the applicability of real options approach to a company of pharmaceutical industry. [Pennings, Sereno, 2011] continues this line of applications. Another line of research papers provide generalized models that allow considering different stages of R\&D project. Paper [Koussis, Martzoukos, Trigeorgis, 2007] elaborate the complex model that accounts for different conditions which company can face within its R\&D process, for example, path-dependence. [Schwartz, 2004] proposes the model to value patents and licenses as real options. This model takes into account uncertainty of future cash flows as well as the possibility of abandoning the project. Classical modification of the Black-Scholes formula introduced in [Margrabe, 1978] was initially used to apply real options in IT industry. Later it proves itself being useful in $R \& D$ literature in the two-stage approach where efficiency of R\&D projects implementation is taken into account.

In this paper we consider one period $R \& D$ investment model dealing with the whole portfolio of real options of a company rather than with each project separately. It will give the possibility of abstracting from diverse types of projects, package solutions, and strategic considerations, which act in 
reality, delegating all responsibility for “optimal" decision to managers. It is assumed that management is able to maintain the portfolio in risk-neutral world defined in the terms of risk neutrality for shareholders. This is a sophisticated skill. It is realistic to expect its validiy only for large public (traded) companies, which are mature in their innovation practices. Risk-neutral probability is determined by stock price volatility since it is associated with customary shareholders' risk. This gives us a possibility to use risk-neutral valuation without exact knowledge of internal decisions (it is impossible to formalize them!). Of course, each project lives in usual real world with its usual (frequency) probability but we deal with portfolio only. This is usual real options approach. We will return to further explanations in the next section.

Our analysis is limited with large innovation extensive companies. Only for such companies we can expect sophisticated managerial skills mentioned above. Being traded in the stock market is also important to proceed with risk-neutral valuation (see Section 2 below). So, our model is not suitable, e.g., for startups or venture businesses, one of the traditional themes of R\&D valuation.

\section{Model assumptions}

The model proposed is based on the following assumptions:

1. The model makes no distinction between different types of research projects that can be undertaken by a company. Thus, instead of considering separate projects, the model focuses on a portfolio of research projects.

2. The single-period model is considered. In the moment $t=0$ a company starts many R\&D projects and therefore allocates a particular amount of money to them. Let us denote this quantity as $R D$. It is not known and should be determined within the model. In the moment $t=T$ all R\&D projects are finished and, as a result, a company may assess the prospects for business development, if any, that stem from any chosen portfolio of projects.

3. Companies perform only those R\&D activities that can result in business development (growth) and therefore derive additional value for shareholders. In other words, the main consequences of an $R \& D$ project are potential investments in real assets that are made at $t=T$ as a result of $\mathrm{R} \& \mathrm{D}$. After $\mathrm{R} \& \mathrm{D}$ period performance is beyond the borders of our model.

4. We consider only mature and large companies in R\&D intensive industries. So we assume that each company has its own budget for potential investments, Inv, which does not fluctuate substantially in time, hence, we can assume it is a known (deterministic) input in the model. Nevertheless, this parameter is unobservable since the set of accepted projects will need only some part of Inv. We will later call it actual volume of investment. Its value is observable and reported by the company.

5. We also can assume that these companies follow a stable debt financing policy. So both $R \& D$ investments and real assets investments, which may follow, are financed from equity and from debt in a smooth way. It is enough to justify formula (8). For derivation of formula (12) we will impose an extra assumption of the use of operational profit as the only source of financing.

6. The value of the company is identified with capitalization (it should be gross of dividends). As it is usual in financial economics we assume that the value follows Geometric Brownian Motion with volatility $\sigma$. Let us treat for simplicity the basic uncertainty as a binary tree 
in one period model (it is easy to generalize this approach to the general continuous case and then use the BlackScholes formula). So, if $S$ is the value of company at $t=0$ then the value at $t=T$ is equal either

$$
S_{u}=S e^{\sigma \sqrt{T}} \text { or } S_{d}=S e^{-\sigma \sqrt{T}} \text {. }
$$

7. Portfolio of accepted R\&D projects allows a company to invest the amount Inv in business development (launching of new products, development of technologies or business processes). These investments may lead to either value creation or value destruction.

8. We assume that volatility of return on value is the same as volatility of return on investments on any set of projects chosen by managers. So if company is ready to invest Inv but the choice of a portfolio of accepted projects will be done at time $t=T$ then the maximum value, which company is ready to spend for $R \& D$, is equal to

$$
R D=\operatorname{Inv}\left(e^{\sigma \sqrt{T}}-1\right)
$$

To derive (2) we subtract expenses from the value of the portfolio estimated with the same growth rate as the company. Strictly speaking, only the part of Inv, which corresponds to accepted projects, will be actually invested. Let us recall that actual $R D$ is now unknown and it will be determined as the main output of our model in the cause of real option analysis. We will add several other assumptions below.

\section{Model for R\&D expenses: company level}

The decision on composition of a portfolio of accepted $R \& D$ projects is a risky project, which we will analyze through the lenses of the real option analysis.
Top managers and R\&D department(s) should be able to decide for each combination of projects being included into portfolio whether it adds or subtracts the value in the terms of risk-neutral behavior determined by basic uncertainty (1). If a company has many projects, then different combinations should be tried. As a part of such choice both usual NPV considerations and many different advanced real options techniques (see, e.g., [Childs, Triantis, 1999]) are used. Here we need our assumption of maturity, since only in a mature company with a lot of experience we can expect that its staff is able to maintain such a sophisticated task. Capitalization and its volatility are both easily observable by managers and important for investors. In these terms, it is often easier to convince the Board of Directors of the proposal. The problem of R\&D projects selection was treated academically in [Cheung, Greenfield, Liao, 2009] where the issue of real options was also under discussion.

Let us add some realistic details concerning the portfolio formation. Not each project that adds value will be added, e.g., sometimes option to wait has higher value then given by (1). On the other hand, some followup options may be accepted because of their future importance. Not only may the real options features of the projects be important. For many advanced technologies elaborated by the companies there is not enough production capacity to produce the required innovative products. This case is known in the microprocessor industry. Direct investment in creating such capacity will dramatically change the risk class of assets in place, so it is not expected. Many patents are not implemented in the production of medications by pharmaceutical companies. In highly competitive industries many projects fail because rival companies could win the innovation race [Gu, 2016]. Of course, we can continue this line of observations further, but let us move to valuation setting.

RMJ 16 (3): 393-406 (2018) 
It is known that some derivatives cannot be evaluated on the basis of risk-neutral probabilities. Robert Merton writes: "The validity of the classic Black-Scholes option pricing formula depends on the capability of investors to follow a dynamic portfolio strategy in the stock that replicates the payoff structure to the option" [Merton, 1976]. In the case of real options it is often not easy to construct tracking portfolio, since many real or intangible assets are not traded. In most cases it is very difficult (if possible at all) to assess their short sales for the purpose of arbitrage. For some projects it is possible sometimes to use outsourcing, licensing, and open innovation approaches to model nontraded assets but for general case we need more general considerations. Our arguments are similar to the case of treating IT-investments as real options [Benaroch, Kauffman, 1999], which follow [Mason, Merton, 1985]. The last paper claims that an arbitrageur can observe deviation of the company's value from usual company or industry trend. Here it is important that we assume all companies to be mature, i. e. their trends are known. Since we identify basic uncertainty with capitalization, which is observable through trading, then this idea works directly.

So we are ready to formulate the following important behavioral assumption:

9. Management team is able to evaluate and then choose portfolios of projects in the risk-neutral world for shareholders.

Denoting the risk-neutral probabilities as $p_{u}$ and $p_{d}$ we apply usual formulas [Hull, 2012]:

$$
\begin{aligned}
& p_{u}=\left(e^{r T}-e^{-\sigma \sqrt{T}}\right) /\left(e^{\sigma \sqrt{T}}-e^{-\sigma \sqrt{T}}\right) \\
& p_{d}=1-p_{u},
\end{aligned}
$$

where $r$ is risk-free rate.
Hence, using formulas (2) and (3) we can assess the expected value, $\overline{R D}$, of R\&D outlays in the risk-neutral world:

$$
\begin{aligned}
\overline{R D} & =p_{u} \cdot R D+p_{d} \cdot 0= \\
& =\frac{\operatorname{Inv} \cdot\left(e^{\sigma \sqrt{T}}-1\right)\left(e^{r T}-e^{-\sigma \sqrt{T}}\right)}{\left(e^{\sigma \sqrt{T}}-e^{-\sigma \sqrt{T}}\right)} .
\end{aligned}
$$

Since the estimate of $\overline{R D}$ in (3) is done assuming risk-neutrality, the amount of money $R D_{0}$ that is equal to this expected value $\overline{R D}$ at $t=0$ can be computed according to the following formula:

$$
\begin{aligned}
R D_{0} & =\overline{R D} \cdot e^{-r T}= \\
& =\frac{\operatorname{Inv} \cdot e^{-r T}\left(e^{\sigma \sqrt{T}}-1\right)\left(e^{r T}-e^{-\sigma \sqrt{T}}\right)}{\left(e^{\sigma \sqrt{T}}-e^{-\sigma \sqrt{T}}\right)} .
\end{aligned}
$$

The evaluation (5) is done in the riskneutral world. It can be interpreted in the following way. If the decision to make investments in real assets is made only after R\&D activities are completed, then the maximum sum that a company can afford to spend on $R \& D$ is $R D_{0}$. Let us emphasize that it is just the value of managerial decisions in accordance to the model. In reality the investment may be a failure at the stage of implementation, i.e., developing assets in place and sales. Nevertheless, the logic of the model still works. For example, in 2010s mobile division of Nokia was investing intensively in $R \& D$ until the acquisition by Microsoft in spite of the fact of dramatic decline in capitalization.

It is noteworthy that Inv is the amount of potential investments, i.e., it is a nonobservable variable that cannot be extracted from companies' financial reporting. In order to empirically test the model of $R \& D$ intensity, it is necessary to link the value $R D_{0}$ with the amount of actually incurred investments, not with the amount of planned investments. Actually incurred investments, $I n v_{a c t}$, can be defined as $I n v_{a c t}=I n v \cdot p_{u}$ and on the basis of (5) the following formula is derived: 


$$
R D_{0}=\operatorname{Inv} v_{a c t} \cdot\left(e^{\sigma \sqrt{T}}-1\right) e^{-r T}
$$

This formula shows the non-linear dependence of R\&D investment on $\sigma$ and $T$. All three inputs are objective and observable.

\section{Model for R\&D expenses: industry level}

Undoubtedly, R\&D expenditures depend not only on the propensity of management to conduct and finance R\&D. Some large companies that are industrial leaders have large R\&D departments with unique equipment. Such companies can spend a lot of money on R\&D. The other large companies may have lower $R \& D$ expenditures because they prefer to buy patents or acquire small innovative companies. These costs will have different accounting treatment. That is why it is difficult to compare R\&D expenditures of different companies, even though they belong to the same industry, because of variety of specific factors. The current paper proposes a model that does not contend to explain R\&D expenditures of a single company; instead, it can be used to explain industrial differences in R\&D expenditures of large companies.

Moving on to the industrial level, it is necessary to average out $R \& D$ expenditures of all companies. Taking into consideration the $R \& D$ diversity across industries, we assume that there is an average life-length of an R\&D project that accounts for industrial specifics $(\bar{T})$. If so, $(6)$ can be written as follows:

$$
R D_{0 ; \text { ind }}=\operatorname{In} v_{a c t ; i n d} \cdot\left(e^{\bar{\sigma} \sqrt{T}}-1\right) \cdot e^{-r \bar{T}},
$$

where $I n v_{a c t ; \text { ind }}$ are actually incurred investments at the industrial level; $\bar{\sigma}$ is typical volatility of value of a large company operating in a particular industry, $\bar{T}$ is average life-length of R\&D project in industry. The indicator $R D_{0 ; \text { ind }}$ represents itself single- time expenses on financing all R\&D projects within the period $\bar{T}$.

It is assumed that companies do not attract external financing for investments in real assets as a result of an R\&D project. For the sake of simplicity, the interest payments and taxes are not considered. Thus, theoretically companies may invest in assets the whole amount of their operating profit.

Now it is the time to add the final assumption (which is actually restrictive, see discussion in Section 6).

10. The model assumes that the amount of investments in real assets is limited to operating profit that company receives in the period $\bar{T}$.

Hence we get

$$
\text { Inv } v_{a c t ; i n d}=O P_{a n ; i n d} \cdot \bar{T},
$$

where $O P_{a n ; i n d}$ is annual operating profit of all companies in the industry. Let us mention that the application of our logic to a single company arrives to formula (8) for this company. But it reality operational profit of a company may well be negative and equality does not make any sense. Our switch to the industry is partly related to this observation since overall operational profit of any industry considered is positive.

In order to compare the model estimates with companies' accounting data, let us assume that R\&D projects are financed uniformly throughout the period $\bar{T}$ :

$$
R D_{0 ; \text { ind }}=\bar{T} \cdot R D_{\text {an;ind }} .
$$

Hence, it is possible to assume that (6) can be used to assess annual R\&D expenditures in the industry:

$$
R D_{a n ; i n d}=O P_{a n ; i n d} \cdot\left(e^{\bar{\sigma} \sqrt{T}}-1\right) \cdot e^{-r \bar{T}} .
$$

The commonly used indicator that allows comparing R\&D activities of companies in different industries is R\&D intensity indica- 
tor (RDI), which is defined (see [Baysinger, Hoskisson, 1989], for example) by the following formula:

$$
R D I_{\text {ind }}=R D_{\text {an;ind }} / R e v_{a n ; i n d},
$$

where $R D I_{\text {ind }}$ are the annual R\&D expenditures and $R e v_{a n ; i n d}$ is annual revenue (sales).

By dividing both parts of (11) by revenue, the following expression is derived:

$$
R D I_{\text {ind }}=p m_{\text {ind }} \cdot\left(e^{\bar{\sigma} \sqrt{T}}-1\right) \cdot e^{-r \bar{T}},
$$

where $p m_{\text {ind }}=O P_{\text {an;ind }} / R e v_{a n ; \text { ind }}$ is average industrial profit margin.

As it is clear from (12), industrial RDI is determined by three main factors: average profit margin, average volatility of large companies' value, and average life-length of an R\&D project in a particular industry. The expression (12) will be henceforth referred to as the research model of the study.

\section{Empirical validation}

In order to empirically apply and test model (12), actual data on large companies from different developed countries (EU, USA, Canada, Japan, Israel and some others) were used. Data were retrieved from electronic dataset prepared for the European Commission report on industrial R\&D investment [Hernández et al., 2017]. In doing so, we intended to test the model on the most recent data available. From the database considered the information concerning companies' revenue, operating margin and R\&D expenditures was obtained.

The criteria of companies' allocation to a particular industry are mentioned in the report and we have not changed them. However, the following companies have been excluded from analysis: (1) companies from developing countries; (2) financial companies; (3) companies with annual revenue less than 100 mln EUR. Additionally, we have excluded four industries with a small number of large companies (less than 10). The resulting sample of 1833 companies from 25 industries was used. For each industry the following indicators were calculated:

- industrial R\&D intensity as the ratio of R\&D expenditures of all companies' in a particular industry to their total revenue in 2016;

- industrial operating profit margin as the ratio of total operating profit of all companies to their revenue.

One of the most difficult issues was the estimation of $\sigma$ for different industries. These estimates cannot be derived from the dynamics of sectoral indices because in this case the values would be underestimated due to the effect of diversification. Hence, it is necessary to analyze the changes in value of the largest companies in the industry and then to average out the estimates of $\bar{\sigma}$.

In the current paper the standard deviation of large and medium US companies' value from A. Damodaran website [Damodaran, 2018] was taken as a proxy of $\bar{\sigma}$. The standard deviation in company value $\sigma$ is computing with the following formula:

$$
\begin{aligned}
\sigma^{2} & =\sigma_{E}^{2} \cdot\left(\frac{E}{V}\right)^{2}+\sigma_{D}^{2} \cdot\left(\frac{D}{V}\right)^{2}+ \\
& +2 \cdot \sigma_{E} \cdot \sigma_{D} \cdot \rho_{E, D} \cdot \frac{E}{V} \cdot \frac{D}{V},
\end{aligned}
$$

where $E$ is equity value, $D$ is debt value, $V=E+D$ is company value, $\sigma_{E}^{2}$ and $\sigma_{D}^{2}$ are variances in equity value and debt value correspondingly, and $\rho_{E, D}$ is correlation coefficient between debt and equity.

The variance in debt value is tough to obtain, so A. Damodaran assumes that it is roughly $40 \%$ of the standard deviation of equity value (based upon the relative volatility in equity and bond indices) and that the correlation between stock and bond prices is 0.5 (again based upon the correlation between equity and bond indices).

As justification for the choice of the standard deviation in company value as a proper 
estimate of $\sigma$ in (12) it is possible to give following arguments. Despite the fact that companies can finance risky R\&D projects, the model assumes that companies generally are willing to finance those R\&D activities that have sound prospects for business. That is why it can be presumed that uncertainty of $R \& D$ results is consistent with the market estimate of uncertainty of a company's value. For this reason, $\bar{\sigma}$ can be assessed as a standard deviation of market value of a company (that can be expressed in terms of stocks and debt volatility).

Table 1 shows the aggregated industrial data for the model verification. Since in database [Damodaran, 2018] the companies

Aggregated industrial data

\begin{tabular}{|c|c|c|c|c|}
\hline Industry & $\begin{array}{l}\text { Number } \\
\text { of companies }\end{array}$ & R\&D intensity & $\begin{array}{c}\text { Average } \\
\text { industrial profit } \\
\text { margin }\end{array}$ & $\bar{\sigma}$ \\
\hline Aerospace \& Defence & 39 & 0.0426 & 0.0956 & 0.512 \\
\hline Automobiles \& Parts & 104 & 0.0483 & 0.0645 & 0.284 \\
\hline Chemicals & 101 & 0.0347 & 0.1119 & 0.388 \\
\hline Construction \& Materials & 41 & 0.0108 & 0.0799 & 0.313 \\
\hline Electricity & 17 & 0.0048 & 0.0809 & 0.156 \\
\hline Electronic \& Electrical Equipment & 168 & 0.0413 & 0.0811 & 0.497 \\
\hline Fixed Line Telecommunications & 10 & 0.0161 & 0.1404 & 0.329 \\
\hline Food Producers & 44 & 0.0143 & 0.1246 & 0.338 \\
\hline Gas, Water \& Multiutilities & 12 & 0.0051 & 0.0353 & 0.214 \\
\hline General Industrials & 60 & 0.0339 & 0.0947 & 0.441 \\
\hline General Retailers & 15 & 0.0108 & 0.0414 & 0.284 \\
\hline Health Care Equipment \& Services & 85 & 0.0329 & 0.0831 & 0.400 \\
\hline $\begin{array}{l}\text { Household Goods \& Home } \\
\text { Construction }\end{array}$ & 33 & 0.0222 & 0.1422 & 0.337 \\
\hline Industrial Engineering & 156 & 0.0349 & 0.0773 & 0.454 \\
\hline Industrial Metals \& Mining & 22 & 0.0096 & 0.0435 & 0.488 \\
\hline Leisure Goods & 31 & 0.0604 & 0.0734 & 0.354 \\
\hline Media & 17 & 0.0313 & 0.0651 & 0.303 \\
\hline Mobile Telecommunications & 12 & 0.0214 & 0.0310 & 0.227 \\
\hline Oil \& Gas Producers & 17 & 0.0044 & 0.0071 & 0.488 \\
\hline Personal Goods & 35 & 0.0197 & 0.1310 & 0.359 \\
\hline Pharmaceuticals \& Biotechnology & 332 & 0.1666 & 0.1879 & 0.632 \\
\hline Software \& Computer Services & 222 & 0.1138 & 0.1630 & 0.460 \\
\hline Support Services & 23 & 0.0364 & 0.1130 & 0.453 \\
\hline Technology Hardware \& Equipment & 223 & 0.0871 & 0.1446 & 0.438 \\
\hline Travel \& Leisure & 14 & 0.0160 & 0.1335 & 0.285 \\
\hline
\end{tabular}

S o u r c : computed by authors based on [Hernandez et al., 2017; Damodaran, 2018]. 
are allocated to 94 industries, volatility data on some of them was aggregated to match the industries listed in the table. It is noticeable that $\bar{\sigma}$ are significantly dependent on industry: the estimates vary from $16 \%$ to $63 \%$ in annual terms.

The average life-length of $R \& D$ projects is difficult to assess for all industries. Anyway, in this empirical study we assume that the average life-length of $R \& D$ projects in different industries is taken as one year, i. e., $\bar{T}=1$. Additionally we can add another reason. Our mature companies run many projects simultaneously in a regular fashion. This regularity gives possibility to think that we can split entire $R \& D$ process in a rolling procedure with one year periods of analysis. In our calculations we ignore the risk-free rate, since it was close to 0 in the developed countries in 2016.

It should be noted that industrial profit margin $(\mathrm{pm})$ and volatility of companies' value $(\sigma)$ that are both included in (12) may not be independent.

\section{Conclusions and further research}

The treatment of $R \& D$ expenditures in the framework of real option analysis and related risk-neutral valuation depends on our main behavioral assumption 9. It is impossible to justify the latter directly. Indirect verification can done through empirical analysis various versions of (6) where (8) is one of options.

As a very preliminary, and far from being sufficient, attempt for such justification we present the following consideration.

Fig. 1 demonstrates the results of comparison of RDI values assessed via (12) and actual RDI values retrieved from companies' annual reports. The data were aggregated to the industrial level, so each dot on the graph represents a particular industry, with actual RDI going on the y-axis and modelled RDI going on the $x$-axis. If the model fitted the empirical data precisely, the modelled
RDI are equal to actual RDI in each industry, so all the dots would lay on a straight line shown in Fig. 1.

The dashed line in Fig. 1 is the graph of the regression function with slope $\hat{k}=1.11$ and the coefficient of determination of $R^{2} \approx 0.71$. The result obtained does not contradict to formula (12) and our suggestion that the model proposed can be used to explain industrial differences in $R \& D$ investment in large companies.

Now let us return to the general setting of the problem. Obviously not only volatility (as it is done in this work) and lifelength of $R \& D$ projects (as we intend to study along the same lines in the future) are relevant factors. The problem of taking in account heterogeneity is the goal of our future study.

The average life-length of $R \& D$ projects is difficult to assess for all industries. According to survey of companies' managers [Whittard et al., 2009] and [Ker, 2013] the average life-length of R\&D does not vary significantly across industries. An average technical R\&D project in non-technological sectors lasts for 1.3 years, while in major technological sectors it lasts for 2 years (the largest life-length of 4.2 years is typical for chemical and pharmaceutical industries). In the meantime, the life-length of nontechnical $R \& D$ projects varies between 0.2 and 0.8 years. Recent studies show that the life-length for drugs industry is much longer [PhRMA, 2015]. So, a lot of aggregation is needed here.

Financing from operational profit is a limitation of the current model. [David, O’Brien, Yoshikawa, 2008] provide deep analysis of R\&D financing from debt. They suggest to distinguish between public and private debt where the first one is not an appropriate tool for investment in intangibles whereas the second works well. Probably it will help to abandon the assumption of all-equity financing, which has been used in this paper. 


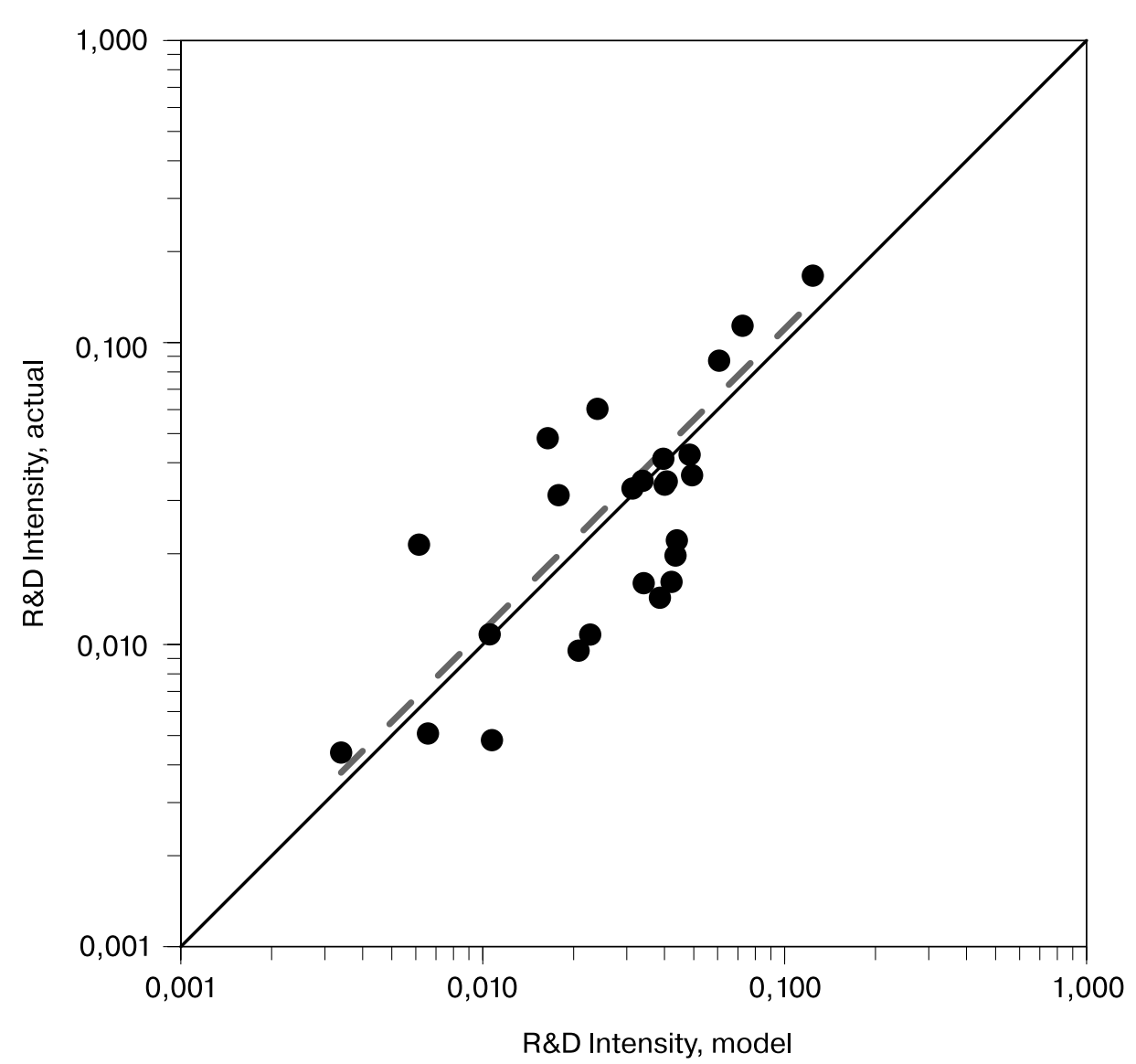

Fig. 1. The comparison of actual and modelled values of R\&D intensity at the industrial level

Let us notice that the challenge of debt financing may be solved (at least theoretically) with sophisticated financial engineering. [Montazerhodjat, Frishkopf, Lo, 2016] consider new dynamic leverage instruments to maintain the debt optimally in the drug producing industry where the recent increase in expenditures is dramatic.

\section{REFERENCES}

Aydin N., Alrajhi A. N., Jouini J.H. 2018. Estimating the impact of R\&D spending on total factor productivity for OECD countries: Pooled mean group approach. Journal of Developing Areas 52 (2): 159-168.

Baysinger B., Hoskisson R.E. 1989. Diversification strategy and $R \& D$ intensity in mul- tiproduct firms. Academy of Management Journal 32 (2): 310-332.

Benaroch M., Kauffman R.J. 1999. A case for using real options pricing analysis to evaluate information technology project investments. Information Systems Research $\mathbf{1 0}$ (1): 70-86. 
Chakravarty A., Grewal R. 2011. The stock market in the driver's seat! Implications for R\&D and marketing. Management Science 57 (9): 1594-1609.

Cheung M.T., Greenfield P.F., Liao Z. 2009. Selecting R\&D projects for technology-based innovation. Journal of General Management 35 (2): $61-80$.

Childs P. D., Triantis A. J. 1999. Dynamic R\&D investment policies. Management Science 45 (10): 1359-1377.

Choi H.-Y., Kwak S.-J., Yoo S.-H. 2016. Using real options pricing to value public $R \& D$ investment in the deep seabed manganese nodule project. Asian Journal of Innovation and Policy 5 (2): 197-207.

Cuervo-Cazurra A., Un C. A. 2010. Why some firms never invest in formal R\&D. Strategic Management Journal 31 (7): 759-779.

Damodaran A. 2018. Standard Deviations by Sector (US). [Electronic resource]. http:// pages.stern.nyu.edu/ adamodar/New Home_Page/datafile/optvar.html (accessed: 12.01.2018).

David P., O'Brien J.P., Yoshikawa T. 2008. The implications of debt heterogeneity for R\&D investment and firm performance. Academy of Management Journal 51 (1): 165-181.

Ding Y., Stolowy H., Tenenhaus M. 2007. R\&D productivity: An exploratory international study. Review of Accounting and Finance 6 (1): 86-101.

$\mathrm{Gu}$ L. 2016. Product market competition, R\&D investment, and stock returns. Journal of Financial Economics 119 (2): 441-455.

Hernández H., Grassano N., Tübke A., Potters L., Amoroso S., Dosso M., Gkotsis P., Vezzani A. 2017. The 2017 EU Industrial $R \& D$ Investment Scoreboard. Publications Office of the European Union: Luxembourg. [Electronic resource]. http://iri.jrc. ec.europa.eu/scoreboard17.html (assessed: 01.06.2018).

Hull J. 2012. Options, Futures and Other Derivatives. 8th ed. Pearson Education.

Jaruzelski B., Schwartz K., Staack V. 2015. Innovation's New World Order. [Electron- ic resource]. https://www.strategy-business.com/feature/00370? gko=e606a (accessed: 18.01.2018).

Kellogg D., Charnes J.M. 2000. Real options valuation for a biotechnology company. $\mathrm{Fi}$ nancial Analysts Journal 56 (3): 76-84.

Ker D. 2013. Service Lives of R\&D Assets: Questionnaire Approach, Office for National Statistic UK. [Electronic resource]. http:// www.ons.gov.uk/ons/dcp171766_304418. pdf (assessed: 01.06.2018).

Koussis N., Martzoukos S., Trigeorgis L. 2007. Real R\&D options with time-to-learn and learning-by-doing. Annals of Operations Research 151 (1): 29-55.

Managi S., Zhang Z., Horie S. 2016. A real options approach to environmental R\&D project evaluation. Environmental Economic Policy Studies 18 (3): 359-394.

Margrabe W. 1978. The value of an option to exchange one asset for another. Journal of Finance 33 (1): 177-186.

Mason S.P., Merton R.C. 1985. The role of contingent claims analysis in corporate finance. In: Altman E.I., Subrahmanyam M. G. (eds) . Recent Advances in Corporate Finance. Richard D. Irwin: Homewood, Ill.; 9-54.

Merton R.C. 1976. Option pricing when underlying stock returns are discontinuous. Journal of Financial Economics 3 (1-2): 125-144.

Montazerhodjat V., Frishkopf J.J., Lo A.W. 2016. Financing drug discovery via dynamic leverage. Drug Discovery Today 21 (3): 410-414.

Newton D.P., Paxson D.A., Widdicks M. 2004. Real R\&D options. International Journal of Management Reviews 5/6 (2): 113-130.

Oriani R., Sobrero M. 2008. Uncertainty and the market valuation of $R \& D$ within real options logic. Strategic Management Journal 29 (4): 343-361.

Paxson D.A. 2001. Introduction to real R\&D options. R\&D Management 31 (2): 109113.

Pennings E., Sereno L. 2011. Evaluating pharmaceutical R\&D under technical and 
economic uncertainty. European Journal of Operational Research 212 (2): 374-385.

PhRMA. 2015. Biopharmaceutical Research \& Development: The Process behind New Medicines. [Electronic resource]. http:// phrma-docs.phrma.org/sites/default/files/ pdf/rd_brochure_022307.pdf (accessed: 10.05.2018).

Schwartz E.S. 2004. Patents and R\&D as real options. Economic Notes by Banca Monte dei Paschi di Siena SpA 33 (1): 23-54.
Teece D.J. 2018. Profiting from innovations in the digital economy: Enabling technologies, standards, and licensing models in the wireless world. Research Policy 47 (8): 1367-1387.

Whittard D., Stam P., Franklin M., Stam P., Clayton T. 2009. Testing an Extended R\&D survey: Interviews with Firms on Innovation Investment and Depreciation. National Endowment for Science Technology and the Arts: London.

Initial Submission: September 1, 2018

Final Version Accepted: September 28, 2018

\section{Приленение реальных опционов для анализа отраслевых затрат на исследования и разработки}

\section{А. В. Бухвалов}

Профессор, Санкт-Петербургский государственный университет, Россия

E-mail: bukhvalov@gsom.pu.ru

\section{А.Е.Лукьянова}

Доцент, Санкт-Петербургский государственный университет, Россия

E-mail: Anna.Loukianova@gsom.spbu.ru

\section{Е.Д. Никулин}

Доцент, Санкт-Петербургский государственный университет, Россия

E-mail: nikulin@gsom.spbu.ru

\section{В.Л.Окулов}

Доцент, Санкт-Петербургский государственный университет, Россия E-mail: okulov@gsom.spbu.ru

Цель настоящей работы состоит в разработке модели, которая может быть использована для оценки величины затрат на исследования и разработки крупных и зрелых компаний. Методология исследования основана на анализе реальных опционов. Затраты на исследования и разработки трактуются в модели как платежи по реальному опциону, который представляет собой право компании инвестировать в будущем в реальные активы и тем самым обеспечивать развитие бизнеса. Основным результатом работы является модель оценки, которая включает в себя несколько релевантных факторов. В то время как в существующих исследованиях подход на основе реальных опционов в основном применяется к анализу отдельных проектов компаний или отдельных отраслей, в настоящей статье данная методология используется для решения более общей задачи. Мы рассчитываем на то, что результаты нашего исследования будут способствовать пониманию различной интенсивности исследовательской деятельности в крупных инновационных компаниях. 
Ключевые слова: затраты на исследования и разработки, портфель исследовательских проектов, реальные опционы, волатильность ценности компании.

JEL: C65, G13, G32, M11, O32.

For citation: Bukhvalov A. V., Loukianova A. E., Nikulin E. D., Okulov V.L. 2018. A real options model for analysis of industrial R\&D expenditures. Russian Management Journal 16 (3): 393406. https://doi.org/10.21638/spbu18.2018.304

https://doi.org/10.21638/spbu18.2018.304

Статья поступила в редакиию 1 сентября 2018 г. Принята к публикации 28 сентября 2018 г. 